\title{
Identification of a small-scale pig farm infected with Brucella suis linked to a clinical case of human brucellosis in Buenos Aires province, Argentina
}

\author{
Bence $\mathrm{AR}^{1,4,5}$, Moran $\mathrm{MC}^{2,4}$, Cacciato $\mathrm{CS}^{2,5}$, Soto $\mathrm{J}^{2,6}$, Gutiérrez $\mathrm{SE}^{3 \phi}$, Estein $\mathrm{SM}^{4^{*} \phi}$ \\ ${ }^{1}$ Departamento de Fisiopatología, Facultad de Ciencias Veterinarias (FCV), Universidad Nacional del \\ Centro de la Provincia de Buenos Aires (UNCPBA). Tandil, Argentina. \\ ${ }^{2}$ Laboratorio de Microbiología Clínica y Experimental, Departamento SAMP. Centro de Investigación \\ Veterinaria de Tandil (CIVETAN)-CONICET-CICPBA. FCV-UNCPBA. Tandil, Argentina. \\ ${ }^{3}$ Laboratorio de Virología, Depto. SAMP. CIVETAN-CONICET-CICPBA. FCV-UNCPBA. Tandil, Argentina. \\ ${ }^{4}$ Laboratorio de Inmunología, Depto. SAMP. CIVETAN-CONICET-CICPBA, FCV-UNCPBA. Tandil, \\ Argentina. \\ ${ }^{5}$ Comisión de Investigaciones Científicas de Buenos Aires (CICPBA). \\ ${ }^{6}$ Laboratorio Biológico de Tandil S.R.L., Tandil, Argentina. \\ * Correspondence: Silvia M. Estein. Campus Universitario s/n, FCV-UNCPBA, Tandil, Argentina. E-mail: \\ similares@vet.unicen.edu.ar \\ ${ }^{\$}$ Contributed equally to this work.
}

Received: 2 February 2021. Accepted: 29 March 2021. Available online: 28 April 2021

Editor: P. Beldomenico

\begin{abstract}
SUMMARY. Here we report a case of human brucellosis due to Brucella suis in a person who worked in a small-scale pig farm. The farm had no history of clinical brucellosis, and signs of the disease were not observed upon clinical examination of the animals. Serum from all the 3 boars, 16/22 sows and 9/25 gilts was obtained for serological examination by Buffered Plate Agglutination Test (BPAT), Rose Bengal Test (RBT) and Fluorescent Polarization Assay (FPA). Bacteriological culture and Direct Fluorescence Antibody Test (DFAT) were performed in tissue samples from a seropositive boar and a sow. Specific antibodies were detected in $53 \%(10 / 19)$ adult pigs, while all sampled gilts were seronegative. B. suis biovar 1 was isolated from one boar. In contrast, while the bacterium was not isolated from any tissue from a seropositive sow, it was detected by DFAT. From the bacteriological and serological evidence of $B$. suis endemic infection in the pig farm and the lack of preventive measures and biosecurity practices, it is concluded that the person most likely acquired the disease from the infected animals or by contact with contaminated environment in the farm.
\end{abstract}

RESUMEN. Identificación de un establecimiento de producción porcina infectado con Brucella suis a partir de un caso clínico de brucelosis humana en la provincia de Buenos Aires, Argentina. En este trabajo reportamos un caso de brucelosis humana ocasionada por Brucella suis en una persona que trabajaba en un establecimiento de producción porcina en pequeña escala. La granja no tenía antecedentes de la enfermedad y los animales no registraban signos clínicos al ser examinados. Se obtuvieron muestras de suero de todos los padrillos $(n=3)$, de $16 / 22$ chanchas y $9 / 25$ cachorras y se analizaron mediante las técnicas de aglutinación rápida en placa con antígeno tamponado (BPA) y Rosa de Bengala (RB) y Polarización de la Fluorescencia (FPA). Muestras de tejido de un padrillo y de una hembra serológicamente positivos fueron analizadas por cultivo bacteriológico y por la técnica de Inmunofluorescencia Directa (IFD). Se detectaron anticuerpos específicos en el $53 \%$ de los cerdos adultos (10/19), mientras que todas las cachorras fueron seronegativas. Se aisló $B$. suis biovar 1 de un padrillo. En contraste, la bacteria no fue aislada en ninguno de los tejidos de la cerda seropositiva aunque sí se detectó la bacteria mediante IFD. A partir de los datos bacteriológicos y serológicos se evidencia la presencia de una infección endémica por $B$. suis. Asimismo, teniendo en cuenta la falta de medidas de prevención y de bioseguridad se concluye que la persona probablemente adquirió la enfermedad por contacto directo con los animales infectados o con el ambiente contaminado con la bacteria. 


\section{Introduction}

Brucellosis continues to be a major public and animal health problem in many regions of the world. This bacterial disease causes reproductive losses resulting from abortion and birth of weak offspring or infertility in all susceptible and accidental hosts.

In most endemic regions, Brucella melitensis is the species most frequently reported as a cause of human disease and the most frequently isolated from cases. However, sporadic cases of human brucellosis due to $B$. suis have been reported in Brazil, Spain, Germany, India and Polynesia (Guerrier et al., 2011; Meirelles-Bartoli et al., 2012; Naha et al., 2012; Compés Dea et al., 2017; Zange et al. 2019). Brucella suis biovar 1 and B. suis biovar 1a with atypical characteristics have been recognized as the major etiological agent of swine and human brucellosis in South America, mainly in Argentina (Lucero et al., 2008; Escobar et al., 2013). Sixty-eight percent of argentine porcine population is located in the provinces of Buenos Aires, Córdoba and Santa Fe. Likewise, small-scale pig farms (i.e., raising less than 100 sows) represent more than $99 \%$ of swine producers (National Service for Animal Health and Food Quality, (SENASA)), operating with low to minimal biosecurity measures with consequent risk for human and animal health, and food or material production. Data on the prevalence of porcine brucellosis in Argentina are scarce. Surveys conducted between 1960 and 1980 found 14.2 to $25 \%$ prevalence (Samartino et al., 2002). In 2017, Dibarbora et al. reported that $6 \%$ of backyard and small-scale pig farms had seropositive animals. This study also showed that none of the producers was aware of the risk factors concerning the transmission of brucellosis from pigs to humans. Diagnosis of porcine brucellosis is performed mainly by serological tests because bacteriological studies are difficult to apply on animals, since they are costly and due to a dearth of facilities and trained personnel.

Brucellosis proved to be a serious occupational health hazard for veterinarians, veterinary technicians, abattoir workers, farmers and laboratory personnel who are frequently exposed to infected animals, or tissues and fluids from these animals (Corbel, 2006). Other reported routes of transmission are ingestion of inadequately cooked meat, inhalation of aerosols containing $B$. suis and contact with an open wound. As reported elsewhere, in Argentina, $B$. suis infections are mainly occupational usually affecting workers of pig slaughterhouses and workers of processing plants (Escobar et al., 2013; Wallach et al., 2016). The symptoms of brucellosis are similar to having the flu, with undulant fever which may progress to a more chronic and debilitating disease. Chronicity and recurring febrile conditions with joint pain are common sequelae. In a series of human cases due to $B$. suis, clinical presentation and complications, apart from a marked increase in alanine aminotransferase levels, were similar to that observed in patients infected with other Brucella spp, like B. mellitensis and B. abortus (Guerrier et al., 2011). Although is a mandatory notifiable-OIE-listed disease in Argentina, cases of human brucellosis still continue to be underdiagnosed and undernotified (Deodato et al., 2011).

Most infected swine do not demonstrate clinical illness, and abortion is generally a minor component of brucellosis presentation. Also, clinical signs of swine brucellosis include orchitis, lameness and abscess formation in various organs (Olsen et al., 2012). Transmission during copulation is frequent and early abortion with return to oestrus may be the only sign. Animals may also be infected by consumption of feed contaminated with uterine discharges, abortion products or urine from infected animals. After exposure, pigs develop a prolonged bacteremia and $B$. suis colonizes the reproductive tract. Pig females usually recover promptly after abortion and they can successfully conceive and give birth to live pigs in future gestations. By contrast, infected boars exhibit few signs of infection although they shed the bacterium in urine and their fertility may be reduced. A significant proportion of pigs will recover from the infection, often within 6 months, but many will remain permanently infected (Olsen et al., 2012).

Diagnosis of swine brucellosis is complicated because its incubation time is quite variable and clinical signs may be absent in endemic farms. Although bacteriological isolation remains the gold standard, this would be unpractical under most conditions (Olsen et al., 2012). For this reason control is based on serological testing and segregation, as well as slaughter of infected breeding stock, or the full depopulation of the affected herd (EFSA, 2009). There is not an available vaccine against this disease in most countries. Limitations in sensitivity and specificity of current serological tests restrict its use at a herd level, rather than for individual animals. The Buffered Plate Agglutination Test (BPAT) or Rose Bengal test (RBT) are most reliable in practice for the identification of infected herds, but they should be combined with other tests, such as the Fluorescent Polarization Assay (FPA), to increase its specificity and sensitivity (Di Febo et al., 2012).

In this report, brucellosis due to $B$. suis was diagnosed in a pig farm, which maintained the infection in an endemic way. This farm was epidemiologically linked to confirmed human brucellosis associated with occupational exposure.

\section{CASE DESCRIPTION}

\section{Case of human brucellosis: Clinical description and} diagnosis

A 27-year-old man manifested intermittent and irregular fever $\left(38^{\circ} \mathrm{C}-39^{\circ} \mathrm{C}\right)$ with high "spikes" reaching $40^{\circ} \mathrm{C}$ or even more in the afternoon, profuse night sweating and weakness for which had begun 1 month 
before. The patient had been working for 6 years in a small-scale pig farm located in Buenos Aires province, Argentina. In an interview, the patient indicated that he had never suffered these symptoms before, and that he had assisted a sow at farrowing 3 weeks before the onset of symptoms (during our study we found this sow positive to all serological tests for brucellosis).

He was attended at the local clinic where laboratory analysis and radiological imaging were prescribed. Number of red blood cell was lower than normal. Ultrasound examination showed enlargement of the spleen (splenomegaly). Positive agglutination reaction in Huddlesson test (titer: 200), BPAT and RBT were obtained with a serum sample. Active brucellosis was diagnosed which was further confirmed through the isolation of $B$. suis biovar 1 after blood culture at the Brucellosis Reference Laboratory (ANLIS-INEI).

The patient start a course with oral doxycycline $(100 \mathrm{mg}$ twice daily) and rifampicin (300 $\mathrm{mg}$ twice daily). Unfortunately, we lost contact with him to follow-up the evolution of symptoms.

\section{Description of the small scale-pig farm}

The pig farm was located in the periurban area of Balcarce district, Buenos Aires, Argentina and comprised: 22 sows, 3 boars and 25 gilts belonging to Yorkshire-Landrace breed, 25 weaned piglets and 12 hogs. The animals were raised in a semi-extensive and self-replacing system: some of them were confined to a simple pen, while others were maintained free in the field, and received agricultural or waste products for feeding. The production was intended both for subsistence and commercial purpose. Some sows were restrained in farrowed crates during delivery and in the first days of lactation. The animals were not adequately identified and serological testing for infectious diseases, including brucellosis, was not routinely performed. The person who was charged for the activities such as feeding, cleaning pens, checking water, farrowing assistance and slaughtering of piglets for sale did not wear adequate protective clothing (i.e. disposable gloves, gown, rubber boots and eye protection). At the beginning of the study, all animals were identified with ear tags.

\section{Diagnosis of brucellosis in the farm}

In order to determine if the source of brucellosis infection was in the small-scale pig farm where the man worked, clinical examination was carried out and records of clinical signs such as abortion, stillbirth, neonatal death, orchitis or lameness were registered. Animals were sampled for serological and bacteriological analysis. All procedures involving animals were approved by the Animal Welfare Committee (act 087/02) of the Facultad de Veterinarias (Universidad Nacional del Centro de la Provincia de Buenos Aires, Tandil, Argentina; http://www.vet.unicen.edu.ar).
Animals did not show any abnormality in external genitalia or joints, neither were records of symptoms compatible with brucellosis in the animals of the farm.

\section{Serological tests}

Only animals accessible to capture were sampled. Blood samples from 16 sows, 3 boars and 9 gilts were collected by jugular veinpuncture. Serum samples were analyzed by conventional agglutination tests, BPAT and RBT, and by FPA (Laboratorio Biológico Tandil S.R.L., Argentina). Fluorescence polarization was measured with a FPM-1 Fluorescence Polarization Analyzer and the results were expressed in milipolarization units $(\mathrm{mP})$. Positive or negative results were determined by the presence or absence of visible agglutination (BPA and RBT) and values $\geq 85 \mathrm{mP}$ (FPA), respectively. Results were interpreted according to the procedures recommended by SENASA (Nicola et al., 2019).

Specific antibodies were detected in $53 \%$ (10/19) adult pigs, while all sampled gilts were seronegative. Ten animals ( $9 / 16$ sows and $1 / 3$ boars) were positive to BPAT, and were confirmed by FPA. Seven sows, two boars and all gilts sampled were negative to all tests. In contrast, two sows and the neutered boar, were positive to BPAT and FPA but they were negative to RBT (Table 1).

Table 1. Results of serological tests on samples obtained from the pigs. BPAT: Buffer Plate Antigen Test; RBT: Bengal Rose Test; FPA: Fluorescence Polarization Assay; P: POSITIVE; N: NEGATIVE.

\begin{tabular}{|c|c|c|c|c|}
\hline \multirow{2}{*}{ Category } & \multirow{2}{*}{ Number of animals } & \multicolumn{3}{|c|}{ Serological test } \\
\hline & & BPAT & RBT & FPA \\
\hline \multirow[t]{2}{*}{ Boars } & 1 & $\mathbf{P}$ & $\mathbf{N}$ & $\mathbf{P}$ \\
\hline & 2 & $\mathbf{N}$ & $\mathbf{N}$ & $\mathbf{N}$ \\
\hline \multirow{3}{*}{ Sows } & 7 & $\mathbf{N}$ & $\mathbf{N}$ & $\mathbf{N}$ \\
\hline & 2 & $\mathbf{P}$ & $\mathbf{N}$ & $\mathbf{P}$ \\
\hline & 7 & $\mathbf{P}$ & $\mathbf{P}$ & $\mathbf{P}$ \\
\hline Gilts & 9 & $\mathbf{N}$ & $\mathbf{N}$ & $\mathbf{N}$ \\
\hline
\end{tabular}

\section{Bacteriological analysis and Direct Fluorescence Antibody Test (DFAT)}

One of the seropositive sows was selected for necropsy, because of its low productivity. Four months after the first serological study, it was bled for the second time and was euthanized using a penetrative captive bolt gun followed by immediate exanguination, and necropsied to perform serological and bacteriological studies. Samples of retropharingeal lymph nodes, tonsils, lung, liver and spleen were obtained and kept in individual sterile plastic bags at $-20^{\circ} \mathrm{C}$. The seropositive boar was neutered and testicles and epididymis were conserved by the same way. Each organ was homogenized with sterile saline and $1 \mathrm{ml}$ of each sample was seeded onto Brucella Agar and in modified Skirrow's medium as previously described (Estein et al., 
2019). Plates were incubated at $37^{\circ} \mathrm{C}$ for 10 days in $5 \%$ $\mathrm{CO}_{2}$ atmosphere. Suspected colonies were identified by Gram staining; catalase, oxidase, urease and nitrate reductase tests and $\mathrm{SH}_{2}$ production (Alton et al., 1988).

To detect Brucella by Direct Fluorescent Antibody Test (DFAT), smears from each organ obtained for the bacteriological study were incubated for $1 \mathrm{~h}$ with fluorescein-labeled anti-Brucella globulin (Laboratorio Biológico de Tandil S.R.L., Argentina). The smears were visualized by a fluorescence microscope with incident illumination at 100x (Zeiss-Primo Star) (Estein et al., 2019).

Gram negative bacteria were isolated from left testicle and left epididymis of the neutered boar. Isolates were identified as B. suis by phenotypic testing (colony characteristics, catalase and oxidase reactions, nitrate reduction, quick urease reaction and $\mathrm{H}_{2} \mathrm{~S}$ production) and were classified as $B$. suis biovar 1 by Brucellosis Reference Laboratory (ANLIS-INEI), Argentina. In addition, smears of these tissues were positive to DFAT (Figure 1). All the tissue samples obtained from the necropsied seropositive sow were negative to bacteriological culture, but all tissues gave positive result in DFAT. Paradoxically, while a serum sample from this sow collected 4 months before was positive in all the serological tests, the serum sample obtained at the time of necropsy was negative to both agglutination tests and positive to FPA (Table 2).

\section{Discussion}

Brucellosis causes economic losses to the swine industry worldwide (EFSA, 2009). In Argentina, a national register of brucellosis-free establishments was created by SENASA (Resolution 63/2013). However, brucellosis control is not mandatory for small-scale pig producers, which are particularly seated in slums, rural and peri-urban areas (SENASA, 2013). System production of small-holders is usually linked to poor conditions of hygiene and lack of appropriate biosecurity measures, which may promote the contact between the pigs themselves, pigs with other domestic animals (i.e. dogs), and pigs with wild animals. The contact of domestic swine with wildlife reservoirs of $B$. suis is considered one of the main risks factors associated with porcine brucellosis (Szyfres et al., 1968).
Table 2. Results of serological and direct tests performed on samples from a sow obtained with a time interval of 4 months. BPAT: Buffer Plate Antigen Test; RBT: Bengal Rose Test; FPA: Fluorescence Polarization Assay; DFAT: Direct Fluorescent Antibody Test; P: POSITIVE; N: NEGATIVE. *Millipolarization units given between parentheses.

\begin{tabular}{|c|c|c|c|c|c|}
$\begin{array}{c}\text { Time of } \\
\text { sampling }\end{array}$ & \multicolumn{2}{|c|}{$\begin{array}{c}\text { Serological } \\
\text { tests }\end{array}$} & \multicolumn{2}{c|}{$\begin{array}{c}\text { Direct } \\
\text { tests }\end{array}$} \\
\cline { 2 - 6 } & BPAT & RBT & FPA* & $\begin{array}{c}\text { Bacteriological } \\
\text { culture }\end{array}$ & DFAT \\
\hline 18 May & P & P & P (210) & Not done & Not done \\
\hline 14 Sep & N & N & P (180) & N & P \\
\hline
\end{tabular}

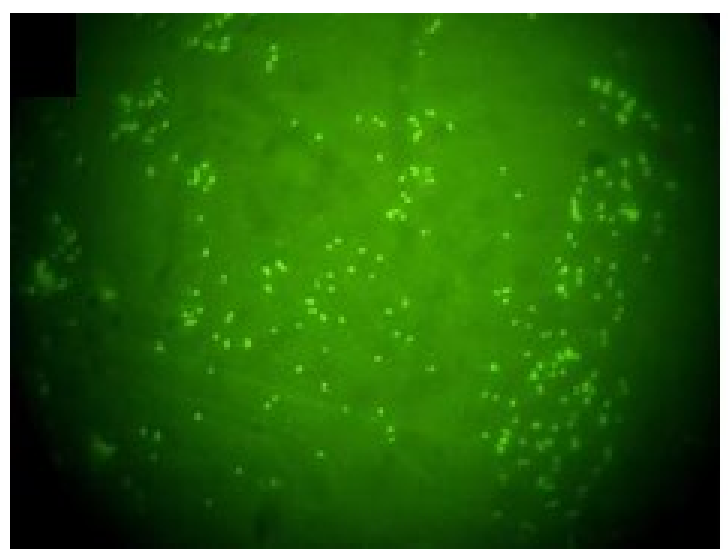

Figure 1. Direct fluorescence antibody test (DFAT) with polyclonal FITC conjugated anti-B. abortus serum. Spleen smear from sow infected with $B$. suis biovar 1 (100x inmersion oil).

Brucellosis is the world's most widespread zoonosis $(500,000$ incident cases of human brucellosis have been reported per year), but also ranks as one of the seven most neglected diseases, according to the World Health Organization (Hull and Schumaker, 2018). Although the true incidence of human brucellosis is unknown in Argentina, of 550 Brucella strains isolated at ANLIS, the reference laboratory for Brucellosis in the country, 11 (20\%) were B. canis, 93 (16.9\%) were B. abortus, 205 (37.2\%) were B. melitensis and $241(43.8 \%)$ B. suis. Of these, 147 (60.9\%) were $B$. suis biovar 1 and 94 (39.0\%) were $B$. suis biovar $1 \mathrm{a}$, which are both endemic in America (Escobar et al., 2013).

In humans, brucellosis caused by $B$. suis is characterized by non-specific acute symptoms, such as fever, malaise, chills, weight loss and arthralgia. In this study, the patient had the most frequent clinical manifestations and splenomegaly. The time elapsed from initial symptoms to diagnosis was one month coincident with the acute phase of this disease. Brucellosis can evolve to chronic signs, which can affect a large number of systems and cause osteomyelitis, orchitis, hepatitis and endocarditis, among other manifestations (Pappas et al., 2005). In our report, the patient received a classical treatment but we cannot follow-up the evolution of the disease. 
The pathophysiology of brucellosis in swine significantly differs from that of brucellosis in large or small ruminants (B. abortus or B. melitensis). Abortion in swine is generally a minor component of the clinical presentation under field conditions (Hutchings et al., 1944, Olsen et al., 2012). The farm described in the present study had not previous clinical or serological records of this disease. However, the serological and bacteriological evidence found in the present study demonstrated that clinically apparently "healthy" pigs carried the infection, in accordance with previous reports (Olsen et al., 2012). Despite agreement in the results of the three serological tests in most of the samples from the swine, 2 sows and 1 boar were positive to BPAT and FPA but negative to RBT. Important differences in the sensitivity/specificity ratios of the serological tests for $B$. suis have been reported, according to the validation criteria and the different epidemiological conditions. A meta-analysis conducted with data from 5 studies showed that RBT was more sensitive than BPAT when the gold standard was the bacteriological culture (EFSA 2009). In other studies, estimates of sensitivity of RBT were lower compared to FPA (Praud et al., 2013), and also to BPAT (Bence et al., 2018). RBT is considered suitable for the diagnosis of $B$. abortus infection in cattle, but may not be sensitive enough for $B$. suis diagnosis in pigs. This may be due, at least in part, to the fact that the agglutination tests and FPA were both mostly developed for detection of the A dominant, $B$. abortus $O$ side-chain in infected cattle (Palmer and Douglas, 1989; Olsen and Tatum, 2017). Moreover, RBT antigen, unlike BPAT antigen, is standardized without reference to the cell concentration but against an OIESS international reference bovine serum, limiting the sensitivity of the RBT in species different from cattle, like sheep and goats (Blasco et al., 1994).

All gilts were negative in the serological tests. These results were probably associated with reduced susceptibility before sexual maturity and pregnancy, as previously reported in other species (Bekele et al., 2011).

Despite the fact that bacteriological culture is considered to be the gold standard method for the diagnosis of Brucella spp., this method is unfeasible in many situations, because it is time-consuming and hazardous, and the bacterium is difficult to isolate from chronically infected swine (Olsen and Tatum, 2017). We could isolate $B$. suis biovar 1 from one testicle and epididymis of one boar, but we could not isolate the bacterium from any tissues from the seropositive sow. However, smears of the tissues from both animals were positive to DFAT, confirming that the sow was indeed infected. The difficulty in isolating the bacteria from the sow may be related to sex differences in the recovery of B. suis as reported (Špičić et al., 2013; Olsen and Tatum, 2017).
Noteworthy, at the time of necropsy, specific antibodies in the infected sow could only be detected by FPA, although previous positive serological results were obtained in both the agglutination tests and FPA. We can speculate that, as it has been reported in human and bovine brucellosis, non-agglutinating or blocking antibodies could have been produced associated to a chronic infection, and, therefore, could only be detected by FPA, a primary binding method (Parma et al., 1984).

Although the serological tests performed in this study do not distinguish between smooth Brucella species infection, bacteriological results allow us to conclude that $B$. suis was the etiological agent. $B$. suis could have been introduced in the farm by the frequent practice of sharing boars for breeding purposes without serological testing and quarantine, which is common in this type of farms.

In view of the results obtained in this study, we advised the owner about control strategies such as quarantine (30 days) for newly purchased animals, serological testing of animals over 45 days at intervals between 30 and 90 days and slaughter of positive animals. Minimal biosecurity practices (i.e. cleaning and disinfection of the pen, feeders and watertroughs with sodium hypochlorite, and wearing protective clothing) were also recommended. In addition, we proposed to delimit clean and dirty zones with perimetral fencing. We also suggested that animals in the clean herd (seronegative) should be fed before those in the dirty herd (seropositive).

From the evidence of endemic infection in the pigs from the farm where the infected human worked and the epidemiological data, we can conclude that the person most likely acquired the disease from the infected animals, or by contact with contaminated environment in the farm. In fact, control strategies such as quarantine, serological screening and slaughter of positive animals, and minimal biosecurity practices had never been applied in the small-scale pig farm where the person worked for 6 years.

The present study highlights the importance of $B$. suis biovar 1 as a cause of occupational exposure to man in an endemically-infected farm where brucellosis had not been previously detected. In addition, our results underscore the need to improve productor's education on appropriate biosecurity measures and to actively screen animals for swine brucellosis.

\section{Acknowledgements}

This work was supported by grant PIP 569 from CONICET (to SME and SEG) and by grant $03 / \mathrm{H} 278-\mathrm{C}$ from SeCYT-UNCPBA. ARB and MCM are recipients of a doctoral fellowship from CICPBA and CONICET, respectively. SME and SEG are members of the Research Career of CONICET. CSC is member technical 
assistant (CICPBA). All authors read and approved the final manuscript. We thank Diego Del Campo (Cambio Rural - Ministerio de Agroindustria de la Nación) who helped in the collection of samples and information from the farm.

\section{References}

Alton GG, Jones LM, Angus RD, Verger JM. 1988. Techniques for the Brucellosis Laboratory. Institut National de la Recherche Agronomique. Paris. 190 pp.

Bekele M, Mohammed H, Tefera M, Tolosa T. 2011. Small ruminant brucellosis and community perception in Jijiga district, Somali Regional State, Eastern Ethiopia. Trop. An. Health Prod. 43: 893-898.

Bence AR, Gutiérrez SE, Risso M, Estein SM. 2018. Aplicación de un modelo bayesiano para estimar la sensibilidad, especificidad y prevalencia de tres pruebas serológicas para el diagnóstico de la brucelosis porcina, sin prueba de referencia. Proceedings of the XXII Reunión Científico Técnica de la Asociación Argentina de Veterinarios de Laboratorios de Diagnóstico, Río Cuarto, Córdoba, Argentina.

Blasco JM, Garin-Bastuji B, Marin CM, Gerbier G, Fanlo J, Jimenez de Bagues. MP, Cau C. 1994a. Efficacy of different Rose Bengal and complement fixation antigens for the diagnosis of Brucella melitensis infection in sheep and goats. Vet. Rec. 134: 415-420.

Compés Dea C, Guimbao Bescós J, Alonso Pérez de Ágreda JP, Muñoz Álvaro PM, Blasco Martínez JM, Villuendas Usón MC. 2017. Epidemiological investigation of the first human brucellosis case in Spain due to Brucella suis biovar 1 strain 1330. Enferm. Infecc. Microbiol. Clin. 35: 179-181.

Corbel MJ. 2006. Food and Agriculture Organization of the United Nations, World Health Organization World Organisation for Animal Health. Brucellosis in humans and animals. World Health Organization. 89 pp.

Deodato BN, Mortarini M, Garro S, Wallach JC. 2011 Retrospective analysis of human brucellosis cases attended in an Infectious Diseases Hospital of Buenos Aires City between years 2008 and 2011. Proceedings of the Brucellosis 2011 International Research Conference. Buenos Aires, Argentina. p. 34.

Dibarbora M, Cappuccio JA, Aznar MV, Bessone FA, Piscitelli H, Pereda AJ, Pérez D R. 2017. Serological detection of Brucella suis, Influenza virus and Aujeszky's disease virus in backyard and small swine holders in Argentina. Rev. Arg. Microbiol. 49: 158-165.

Di Febo T, Luciani M, Portanti O, Bonfini B, Lelli R, Tittarelli M. 2012. Development and evaluation of diagnostic tests for the serological diagnosis of brucellosis in swine. Vet. Ital. 48: 133156.

EFSA (European Food Safety Authority). (2009). Porcine brucellosis (Brucella suis), Scientific Opinion of the Panel on Animal Health and Welfare (AHAW). https://doi.org/10.2903/i.efsa.2009.1144.
Escobar GI, Jacob NR, López G, Ayala SM, Whatmore AM, Lucero NE. 2013. Human brucellosis at a pig slaughterhouse. Comp. Immunol. Microbiol. Infect. Dis. 36: 575-580.

Estein SM, Bence AR, Cacciato CS, Echevarría HM, Soto P. 2019. Comparison of Direct Fluorescent Antibody Test and bacteriological culture for detection of Brucella spp. Application to demonstrate Brucella suis in swine tissues. Rev. Vet. (UNNE) 30: 9-42.

Guerrier G, Daronat JM, Morisse L, Yvon JF, Pappas G. 2011. Epidemiological and clinical aspects of human Brucella suis infection in Polynesia. Epidemiol. Infect. 139: 1621-1625.

Hull NC, Schumaker BA. 2018. Comparisons of brucellosis between human and veterinary medicine. Infect. Ecol. Epidemiology 8: 1500846.

Hutchings LM, Delez AL, Donham CR. 1946. Brucellosis in swine; reproduction studies with naturally infected sows and boars. Am. J. Vet. Res. 7: 388-394.

Lucero NE, Ayala SM, Escobar GI, Jacob NR. 2008. Brucella isolated in humans and animals in Latin America from 1968 to 2006. Epidemiol. Infect. 136: 496-503.

Meirelles-Bartoli RB, Mathias LA, Samartino LE. 2012. Brucellosis due to Brucella suis in a swine herd associated with a human clinical case in the State of São Paulo, Brazil. Trop. Anim. Health Prod. 44: 1575-1579.

Naha K, Dasari S, Pandit V, Seshadri S. 2012. A rare case of seronegative culture-proven infection with Brucella suis. Australas. Medical J. 5: 340-343.

Nicola A, Elena S. 2019. Manual de diagnóstico serológico de la brucelosis bovina. Servicio de Sanidad y Calidad Agroalimentaria (SENASA), Argentina.

Olsen SC, Garin-Bastuji B, Blasco JM, Nicola AM, Samartino L. 2012. Brucellosis. In: "Diseases of Swine", 10th Edition. Pp: 697-708.

Olsen SC, Tatum FM. 2017. Swine brucellosis: current perspectives. Vet. Med. Res. Rep. 8: 1-12.

Palmer DA, Douglas JT. 1989. Analysis of Brucella lipopolysaccharide with specific and cross-reacting monoclonal antibodies. J. Clin. Microbiol. 27: 2331-2337.

Pappas G, Akritidis N, Bosilkovski M, Tsianos E. 2005. Brucellosis. N. Engl. J. Med. 352: 2325-2236.

Parma AE, Bowden RA, Santisteban CG, Cerone SI, Fernandez AS. 1987. Effect of bovine non-agglutinating antibodies on the blood clearance of 131l-labelled Brucella abortus strain 45/20. Vet. Microbiol. 15: 121-128.

Praud A., Gimenez O, Zanella G, Pozzi N, Antras V, Meyer L, Garin-Bastuji B. 2013. Evaluation of five serological tests for the diagnosis of porcine brucellosis in French Polynesia. Trop. An. Health. Prod. 45:931-933.

Samartino LE. 2002. Brucellosis in Argentina. Vet. Microbiol. 90: 71-80. 
SENASA. 2013. Resolución 63/2013. Retrieved from http://www. senasa.gob.ar/normativas/resolucion-632013.

Špičić S, Zdelar-Tuka M, Račić I, Vujnović A, Miroslav B, Duvnjak S, Cvetnić Ž. 2013. Sensitivity of actual laboratory diagnostic methods used for surveillance of swine brucellosis in Croatia. J. Appl. Res. Vet. Med. 11: 167-173.

Szyfres B, González Tomé J, Palacio Mendieta T. 1968. Aislamiento de Brucella suis de la liebre europea (Lepus europaeus) en la Argentina. Bol. Oficina Sanit. Panam. 65 (5).

Zange S, Schneider $\mathrm{K}$. Georgi E, · Scholz HC, Antwerpen MH, Walter MC, Zoeller L, von Buttlar H, Borde JP. 2019. A headache with surprising outcome: first case of brucellosis caused by Brucella suis biovar 1 in Germany. Infection 47: 863868. 